IRA-International Journal of Management \&

Social Sciences

ISSN 2455-2267; Vol.10, Issue 02 (February 2018)

Pg. no. 87-93.

Institute of Research Advances

http://research-advances.org/index.php/RAJMSS

\title{
A Comparative Study of Work-Life Balance and Job Satisfaction of the Employees Working in Business Process Outsourcing Sector
}

\author{
Subooh Yusuf \\ Research Scholar, Psychology, Aligarh Muslim University, India.
}

Type of Review: Peer Reviewed.

DOI: http://dx.doi.org/10.21013/jmss.v10.n2.p3

\section{How to cite this paper:}

Yusuf., S. (2018). A Comparative Study of Work-Life Balance and Job Satisfaction of the Employees Working in Business Process Outsourcing Sector. IRA-International Journal of Management \& Social Sciences (ISSN 2455-2267), 10(2), 87-93. doi:http://dx.doi.org/10.21013/jmss.v10.n2.p3

(C) Institute of Research Advances.

\section{(cc) BY-No}

This work is licensed under a Creative Commons Attribution-Non Commercial 4.0 International License subject to proper citation to the publication source of the work.

Disclaimer: The scholarly papers as reviewed and published by the Institute of Research Advances (IRA) are the views and opinions of their respective authors and are not the views or opinions of the IRA. The IRA disclaims of any harm or loss caused due to the published content to any party.

Institute of Research Advances is an institutional publisher member of Publishers Inter Linking Association Inc. (PILA-CrossRef), USA. The institute is an institutional signatory to the Budapest Open Access Initiative, Hungary advocating the open access of scientific and scholarly knowledge. The Institute is a registered content provider under Open Access Initiative Protocol for Metadata Harvesting (OAI-PMH).

The journal is indexed \& included in WorldCat Discovery Service (USA), CrossRef Metadata Search (USA), WorldCat (USA), OCLC (USA), Open J-Gate (India), EZB (Germany) Scilit (Switzerland), Airiti (China), Bielefeld Academic Search Engine (BASE) of Bielefeld University, Germany, PKP Index of Simon Fraser University, Canada. 


\begin{abstract}
This paper provides an insight into the Work life balance and job satisfaction of individuals working in business process outsourcing. In the present fast growing scenario, people don't have time for themselves or for their families. It is difficult to balance both work and personal life at a time, especially for the employees working in Business process outsourcing (BPO's).The Work life balance of an individual is one of the factors, which affect their satisfaction or happiness with life as a whole.. Data was obtained from 200 employees, 120 male and 80 female. Work life balance was measured by the 15-item scale developed by Fisher-McAuley (2003), consist of three dimensions - work interference with personal life (WIPL), personal life interference with work (PLIW), work/personal life enhancement (WPLE) and job satisfaction was measured by using scale Khan and Sheeba (2002).Data comparison of work life balance, its three dimensions work interference with personal life, work/personal life enhancement, personal life interference with work and job satisfaction between male and female t-test was found suitable. All the analysis was carried out with the help of the computer using SPSS 16.0 version.
\end{abstract}

Keywords: Business process outsourcing, Job satisfaction, SPSS, t-test, Work life balance.

India, business process outsourcing is the fastest growing segment of the ITES industry. Factors such as economy of scale, business risk mitigation, cost advantage; utilization improvement and superior competency have all lead to the growth of the Indian BPO industry.

In the present fast growing scenario, people don't have time for themselves or for their families. It is difficult to balance both work and personal life at a time, especially for the employees working in Business process outsourcing (BPO's). American, US and UK based companies. BPO's in India work according to their country timings which becomes very hectic for the Indian employees. India, business process outsourcing is the fastest growing segment of the ITES industry. Factors such as economy of scale, business risk mitigation, cost advantage; utilization improvement and superior competency have all lead to the growth of the Indian BPO industry.

\title{
Literature Review
}

Work life balance was first used in the United Kingdom in the late 1970s to describe balance between an individual's work and personal life. Work-life balance consist of two words that is work which is related to ambition, career and life is related to family, health, pleasure though broader, terms are "lifestyle calm balance" and "lifestyle choices".

Frone et al. (1992a) found no evidence of gender differences in the pattern of asymmetry, indicating that the dynamics of work and family boundaries may operate similarly among men and women.

Campbell and Kennard (1994) have studied the effects of family responsibilities on the work commitment and job performance of women. The work-family issue is even further expanded to address the relationship of business-marriage partners (Foley \& Powell, 1997).

Burke, (2002) found out that both women and men prefer working in organization's that support worklife balance. Women are more affected by improper work life balance as compared to men, women feel frustrated, unhappy, full of stress if they are not able to give time to their family.

Aziz and Cunningham, (2008) in a study found work stress and work-life imbalance were correlated with work holism, regardless of gender.

Baral (2010) in a study of 485 employees working in varied organizations in India found that working men and women in India experience more work family enrichment than the work family conflict. It was also found that there were no gender differences in the employee perception of work family enrichment.

Klopping (2012) contribution, in the modern times, human resource department's one of the major emphasis is to maintain a balance between the professional and the personal life.

Job satisfaction refers to a person's feeling of satisfaction on the job, which acts as a motivation to work. Job satisfaction include employees' economic benefits, the social status, the job's own specific characteristics and the job expectation employees hoped for, if all are fulfilled then there is job 
satisfaction. Job satisfaction has been a subject to scientific researches with Hawthorne studies in 20th centuries. Job satisfaction is described as pleasurable or positive emotional state as a result of evaluation of the job or job experiences. Job satisfaction is the feeling combination of workers both positive and negative. Job satisfaction represents the extent to which expectations are and match the real awards. Job satisfaction is closely linked to that individual's behavior in the work place (Davis et al., 1985).

Allen, Herst, Bruck, \& Sutton, (2000) demonstrated relationships between conflict and lower job satisfaction and enhancement and higher job satisfaction. Bruce and Blackburn (1992) also believed that job enrichment increases job satisfaction. They defined an enriched job as one that offers the employee opportunities for achievement, recognition, advancement, responsibility, and growth.

A study conducted on nurses, (Shields and Ward 2001) found that the lack of opportunities for career advancement or the possibility of promotion affect the job satisfaction of employees more than the size of the salary.

Bruck (2002) examined whether there would be differential relationship across the job satisfaction facets. These tests revealed no significant differences across facets for any of the conflict measures. These results provide important implications for practitioners who are implementing organizational interventions designed to combat work family conflict.

Robbins (2004) observed that persons with high level of job satisfaction hold positive attitudes about their jobs while persons who are dissatisfied hold negative attitudes about their jobs.

Kinnie, Hutchinson, Purcell, Rayton, (2005) in a study found that satisfaction with the HR practices, such as family friendly policies reduced the interference of work in the family and thus increases job satisfaction.

\section{Objectives:}

To compare work life balance of male and female working in BPO's.

To compare job satisfaction of male and female working in BPO's.

\section{Hypotheses:}

$\mathbf{H}_{1}$ : It is expected that difference exists of job satisfaction among male and female employees of BPO sector.

$\mathbf{H}_{2}$ : It is expected that difference exists of work life balance among male and female employees of BPO sector.

\section{Methodology}

Sample: The sample of present research comprises of 200 employees (where 120 males, and 80 females) randomly, selected from different BPO's of Aligarh and Delhi.

Tools:

\section{The Work Life Balance Inventory}

Work life balance was measured with a 15 item scale adapted by Hayman (2005), originally developed by Fisher (2001).This broader approach is useful for organizations to assess the non-work domain of employees, as family may not be relevant to all employees. Moreover this scale also measures positive spill over or enhancement (Hayman, 2005). The scale consisted of 15 items, designed to assess three dimensions of work life balance, i.e., work interference with personal life (WIPL-7 items), personal life interference with work (PLIW-4 items), and work/personal life enhancement (WPLE-4 items). The first dimension, work interference with personal life (WIPL) included the items e.g. - Personal life suffers because of work and -Put personal life on hold for work. These items reveal the extent to which work interferes with personal life. The second dimension is work interference with personal life (WIPL). The items included in this component indicate the opposite direction of work personal life interference. Examples of the items include - My work suffers because of my personal life and - It is hard to work because of personal matters. They illustrate the extent to which ones 'personal life interferes with work. The items of the third dimension work/personal life enhancement (WPLE) involved positive effects of ones 'work on personal life or vice versa, the extent to which ones 'personal life increases work. Examples of the items included were, -I have a better mood at work because of personal life and -I have a better mood because of my job. Here, the scale is 5 point (Strongly Disagree -1, Disagree - 2, Neither Agree nor Disagree- 3, Agree -4, Strongly Agree -5), the scoring was done as 5, 4, 3, 2, 1 for 
the dimensions of WIPL (except item 7, which was reverse scored, i.e. and PLIW, since the items were negatively worded. High score indicated lower interference and, lower levels of interference were interpreted as higher levels of work life balance. For the dimension of WPLE, scoring was 1,2,3,4,5,6,7 (i.e. (Strongly Disagree -1, Disagree -2, Neither Agree nor Disagree- 3, Agree -4, Strongly Agree - 5)as the items were positively worded. High score indicated high work/ personal life enhancement. Higher levels of work/ personal life enhancement are considered to be associated with higher levels of work life balance. The overall work life balance score was thus computed by adding the scores on the three dimensions. Results of higher order factor analysis provided empirical evidence that the three dimensions were indicators of a single latent construct (Fisher-McAuley, et al., 2003). Reliability for the scale, estimated using Cronbach alpha coefficient was .91 for WIPL, .82 for PLIW and .67 for WPLE. The scale was tested for reliability under the Indian conditions and Cronbach alpha was found to be .87 .

\section{Job Satisfaction}

The job satisfaction scale developed by Khan and Sheeba 2002 was used. In this scale there are 25 items and each item to be rated on a five-point scale ranging on the continuum of very much satisfied to not satisfied at all and the waited scores should be marked 5,4,3,2 and 1

The scores on job satisfaction will be ranging from 25 to 125 . Subjects lowest score will be 25 and the highest will be 125 . The coefficient correlation of the scores using spilt half reliability method was found to be 0.77 .

\section{Statistical analysis:}

The choice of statistical analysis depends on purpose and objective so framed, here it is intended to investigate the comparison between work life balance and job satisfaction among employees of BPO's for that investigator applied t-test between women and men.

\section{Result and Discussion}

The present study attempted to assess the comparison of work life balance and job satisfaction of employees working in business process outsourcing sector.

The t-test is applied for the purpose of statistical interpretation.

Table-1: Showing $t$ value, Mean and SDs between male and female employees of BPO sector

\begin{tabular}{|c|c|c|c|c|c|c|c|}
\hline \multirow{2}{*}{ S. No } & Variables & \multicolumn{2}{|c|}{ Male( N=120) } & \multicolumn{2}{|c|}{ Females(N=80) } & \multirow{2}{*}{ T } & \multirow{2}{*}{ sig } \\
\cline { 3 - 6 } & & Mean & S.D. & Mean & S.D & & \\
\hline 1 & Job satisfaction & 86.88 & 12.942 & 88.11 & 13.035 & -.661 & .954 \\
\hline 2 & Work life balance & 50.54 & 8.596 & 50.56 & 9.774 & -.016 & .116 \\
\hline
\end{tabular}

The first variable indicates comparison of male and female of BPO sector on job satisfaction. The result shows the mean job satisfaction score of female is higher than the male employees. The mean score of male is 86.88 and for the female employees is88.11. The SD of the male is found to be 12.942 and for female is 13.035 . The $\mathrm{t}$ value obtained is -.611 which is insignificant showing that male and female do not differ with regard to job satisfaction, so the hypothesis is rejected.

The mean work life balance score of female is higher than the male employees. The mean score of male is 50.54 and for the female employees is 50.56 . The SD of the male is found to be 8.596 and for female is 9.774 .The $t$ value obtained is -.016 which is insignificant showing that male and female overall do not differ with regard to work life balance, so the hypothesis is rejected.

\section{Conclusion:}

It may be concluded that male and female BPO's employees were not differ with each other with regard to the above variables means both similarly affected by the variables. Insignificant difference was found between job satisfaction among male and female employees of BPO sector. Liacqua \& Schumacher, (1995) in a study revealed that demographic factors (age, gender, degree) have little or no impact on job satisfaction. In contrast, the results indicated a relationship between selected 
demographic factors and job dissatisfaction. A study by Ward and Sloane (2000), however, concluded that there are significant differences in job satisfaction levels based on the gender and disciplinary affiliation of faculty members.

Significant difference was not found between work life balance among male and female employees of BPO sector. Hill et al. (2001) reported that gender was not significantly correlated to work and family balance indicating that men and women report similar level of work family balance.

\section{References:}

[1] Aziz,S., \& Cunningham J., (2008). Workaholism, work stress, work-life imbalance: exploring genders role. Gender in Management: An International Journal,Vol.23, Iss: 8, pp.553-566, Emerald Group Publishing Limited.

[2] Baral, R. (2010). Work-family enrichment: Benefits of combining work and family. Retrieved October 7 , 2010, from http://www.paycheck.in/main/work-andpay/women-paycheck/articles/work-familyenrichment-benefits-of-combiningwork-and-family.

[3] Bruck, C. et al. (2002). The Relation between Work-Family Conflict and Job Satisfaction: A FinerGrained Analysis. Journal of Vocational Behavior, 60(3): 336-353.

[4] Frone, M. R. (2002). Work-family balance. In J. C. Quick \& L. E. Tetrick (Eds.), Handbook of Occupational Health Psychology. Washington, DC: American Psychological Association.

[5] Kinnie Nicholas, Hutchinson Sue, Purcell John, Rayton Bruce and Swart Juani. (2005). Satisfaction with HR practices and commitment to the organization: why one size does not fit all. Human Resource Management Journal, Vol. 5, No. 4,P. 9-29.

[6] Klopping, L. (2012). - Work-Life-Balance. GRI Verlag.

[7] Robbins, .S.P. (2004).Organisational Behaviour (10th edn.). New Delhi: Prentice Hall of India, Pvt. Ltd.

[8] Shields, M. and Ward, M. (2001).Improving nurse retention in the National Health Service in England: The impact of job satisfaction on intentions to quit. Journal of Health Economics, 20, pp. $677-701$. 


\section{APPENDIX- I}

\section{JOB SATISFACTION SCALE}

INSTRUCTIONS- Dear respondent you are requested to go through the various facts/job related characteristics one by one and rate them on five point scale. The responses given by you shall be kept confidential and be used only for academic purposes. Your cooperation in this regard shall be highly appreciated.

Not satisfied at all assign

Not satisfied

Cannot say

Satisfied

Very much satisfied
1

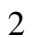

3

4

5

\begin{tabular}{|l|l|l|}
\hline 1 & Self esteem or respect & \\
\hline 2 & Prestige of job inside the department & \\
\hline 3 & Prestige of job outside the department & \\
\hline 4 & Opportunity for professional growth & \\
\hline 5 & Opportunity for outside the department & \\
\hline 6 & Pay for job & \\
\hline 7 & Amount for close supervision & \\
\hline 8 & Opportunity for close friendship & \\
\hline 9 & Opportunity to help other & \\
\hline 10 & Feeling of job security & \\
\hline 11 & Opportunity to complete work & \\
\hline 12 & Feeling of accomplishment & \\
\hline 13 & Opportunity to get to know others & \\
\hline 14 & Liking for the nature of the work & \\
\hline 15 & $\begin{array}{l}\text { Comforts of physical working conditions(place } \\
\text { of work, transportation light etc. }\end{array}$ & \\
\hline
\end{tabular}




\section{APPENDIX -II \\ Questionnaire}

Dear Respondent,

You are requested to kindly provide your responses. Please be assured that your responses will be kept confidential and will be used for academic purpose only.

\section{SD- Strongly Disagree (1) =======> SA-Strongly Agree (5)}

\begin{tabular}{|c|c|c|c|c|c|c|}
\hline S.N & Statements & $\begin{array}{c}\text { Strongly } \\
\text { Disagree } \\
\text { (1) }\end{array}$ & $\begin{array}{c}\text { Disagree } \\
\text { (2) }\end{array}$ & $\begin{array}{c}\begin{array}{c}\text { Neither } \\
\text { Agree }\end{array} \\
\text { nor } \\
\text { Disagree } \\
\text { (3) }\end{array}$ & $\begin{array}{r}\text { Agree } \\
\text { (4) }\end{array}$ & $\begin{array}{c}\text { Strongly } \\
\text { Agree } \\
\text { (5) }\end{array}$ \\
\hline 1 & $\begin{array}{l}\text { My personal life suffers because of } \\
\text { work }\end{array}$ & & & & & \\
\hline 2 & My job makes personal life difficult & & & & & \\
\hline 3 & $\begin{array}{l}\text { I neglect personal needs because of } \\
\text { work }\end{array}$ & & & & & \\
\hline 4 & I put personal life on hold for work & & & & & \\
\hline 5 & $\begin{array}{l}\text { I miss personal activities because of } \\
\text { work }\end{array}$ & & & & & \\
\hline 6 & I struggle to juggle work and non-work & & & & & \\
\hline 7 & $\begin{array}{l}\text { I am unhappy with the amount of time } \\
\text { for non-work activities }\end{array}$ & & & & & \\
\hline 8 & $\begin{array}{l}\text { My personal life drains me of energy } \\
\text { for work }\end{array}$ & & & & & \\
\hline 9 & I am too tired to be effective at work & & & & & \\
\hline 10 & $\begin{array}{l}\text { My work suffers because of my } \\
\text { personal life }\end{array}$ & & & & & \\
\hline 11 & $\begin{array}{l}\text { It is hard to work because of personal } \\
\text { matters }\end{array}$ & & & & & \\
\hline 12 & $\begin{array}{l}\text { My personal life gives me energy for } \\
\text { my job }\end{array}$ & & & & & \\
\hline 13 & $\begin{array}{l}\text { My job gives me energy to pursue } \\
\text { personal activities }\end{array}$ & & & & & \\
\hline 14 & $\begin{array}{l}\text { I have a better mood at work because of } \\
\text { personal life }\end{array}$ & & & & & \\
\hline 15 & I have a better mood because of my job & & & & & \\
\hline
\end{tabular}

Gender: Male / Female

Qualification:

Department:

Current grade/ position in organization: Manager/ Assistant Manager/ Clerk

Years of Work Experience: <5yrs / 5-10 yrs/ > 10 yrs

Thank You 